\title{
SISTEM NOTIFIKASI TUGAS AKHIR UNIVERSITAS BINA DARMA BERBASIS MOBILE
}

\author{
${ }^{1}$ Ryan Andri, ${ }^{2}$ Nurul Adha Oktarini Saputri*, ${ }^{3}$ Muhamad Akbar \\ 1,2,3 Teknik Informatika, Ilmu Komputer, Universitas Bina Darma, \\ Jalan Jendral Ahmad Yani No. 12 Palembang \\ Email: ryan-andri@outlook.com, nuruladhaos@binadarma.ac.id, muhamad.akbar@binadarma.ac.id \\ *Corresponding Author: nuruladhaos@ binadarma.ac.id
}

(Diterima: 1 November 2019, direvisi: 22 Desember 2019, disetujui: 28 Desember 2019)

\begin{abstract}
On the cell phone devices, a notification is a deliver information or a short information. Through this notification, cell phone users will easily get information in their cell phone. At Bina Darma University, the students' final project notification is still sent through email. So it can prevent students to get important information in terms of the final project quickly, because not every student always uses email. Based on this problem, the idea arised to conduct a research and development of students' final project notifications of Bina Darma University with mobile -based. It was aimed to create a mobile software which can deliver notifications about student's final project. The methodology in this development used the Mobile-D method. The programming language in this development used the Java programming language and the PHP website programming language and database creation using MySQL. This development also used API support (Application Programing Interface) Firebase Cloud Messaging and Android Studio for manufacturing mobile software.
\end{abstract}

Keywords: Android, Firebase, Notifications, Mobile-D

\begin{abstract}
ABSTRAK
Pada perangkat telepon seluler, notifikasi merupakan penyampaian pesan atau informasi secara singkat, sehingga dengan adanya notifikasi pengguna telepon seluler dapat terbantu dalam hal yang bersifat pemberitahuan atau penyampaian informasi secara singkat. Pada Universitas Bina Darma, notifikasi tugas akhir mahasiswa masih disampaikan melalui email, hal ini bisa menghambat mahasiswa untuk dapat informasi penting dalam hal tugas akhir dengan cepat, dikarenakan tidak setiap mahasiswa selalu menggunakan email, oleh sebab itu munculah gagasan untuk melakukan penelitian pengembangan notifikasi tugas akhir mahasiswa Universitas Bina Darma yang berbasis mobile dengan tujuan yaitu membuat sebuah perangkat lunak mobile yang mampu menyampaikan notifikasi yang berhubungan dengan tugas akhir mahasiswa. Metodologi dalam pengembangan ini menggunakan metode Mobile-D. Bahasa pemrograman dalam pengembangan ini menggunakan bahasa Java dan bahasa pemrograman website PHP serta pembuatan database menggunakan MySQL. Pengembangan ini juga menggunakan dukungan API (Aplication Programing Interface) Firebase Cloud Messaging dan Android Studio untuk pembuatan perangkat lunak mobile.
\end{abstract}

Kata Kunci: Android, Firebase, Notifikasi, Mobile-D

\section{PENDAHULUAN}

Sistem notifikasi digunakan sebagai sarana dalam melakukan pemberitahuan atau penyampaian informasi dari sistem ke sistem yang lain. Notifikasi berasal dari bahasa inggris notification yang berarti pengingat atau sebuah pemberitahuan yang melalui suatu media. Media tersebut merupakan sarana dalam penyampaian suatu notifikasi yang dapat dilakukan melalui pengiriman e-mail.

Surat elektronik (e-mail) adalah kegiatan surat-menyurat yang tidak menggunakan pos sebagai media pengiriman, tetapi menggunakan jaringan internet sebagai media pengirimannya, jadi setiap orang yang ingin melakukan kegiatan surat-menyurat dengan e-mail harus ada komputer atau laptop ataupun menggunakan handphone dan terutama harus ada fasilitas internet. 
Melalui perkembangan teknologi perangkat mobile sekarang, notifikasi atau pemberitahuan dapat langsung dikirim dan diterima ke perangkat mobile lainnya yang disebut dengan push notification. Push Notification "adalah sebuah layanan yang banyak digunakan untuk keperluan pemberitahuan melalui pesan pendek yang ada di smartphone. Dengan adanya layanan Push Notification tersebut, pengguna dapat terbantu dalam hal yang bersifat pemberitahuan secara singkat"[1]. "Notifikasi memberikan layanan penting yaitu membantu user mengelola tugas dan perubahan informasi dalam aplikasi yang digunakannya, dengan adanya notifikasi pada perangkat mobile dapat membantu mengingatkan user akan tugas yang harus dijalankan" [2].

Salah satu perangkat mobile yang sudah sangat umum digunakan yaitu telepon seluler atau smartphone berbasis android. Android "merupakan salah satu sistem operasi yang dipergunakan pada telepon seluler dan komputer tablet layar sentuh (touch screen) dengan berbasis Linux. Basis sistem operasi android adalah kernel linux yang merupakan open source sehingga sistem operasi android memungkinkan pengembang untuk selalu menciptakan aplikasi android sendiri yang bisa digunakan untuk berbagai macam alat yang bergerak (mobile)" [3]. Android "adalah suatu sistem operasi yang berbasis pada perangkat mobile. Android menganut sistem open source yang memudahkan bagi setiap pengembang yang ingin mengembangkan atau membuat suatu aplikasi pada ponsel dengan platform android" [4]. Telepon seluler sudah menjadi bagian dari kebutuhan sehari-hari mulai dari sarana untuk berkomunikasi, mencari berita hingga kirim mengirim e-mail (surat elekronik) serta dapat menerima notikasi atau pemberitahuan dari media yang dapat berupa informasi.

Sistem notifikasi tugas akhir di Universitas Bina Darma saat ini masih menggunakan basis layanan e-mail atau surat elektronik. Pada proses pengambilan proposal tugas akhir, mahasiswa harus melengkapi persyaratan pengambilan proposal tugas akhir mulai jumlah sks yang telah di ambil minimal 130 sks serta bukti pembayaran administrasi akademik untuk diserahkan ke PPM (Pusat Pelayanan Mahasiswa) guna untuk penentuan kelayakan pengambilan proposal tugas akhir dan dilanjutkan dengan pengajuan judul kepada pembimbing masing - masing dari setiap mahasiswa. Selanjutnya, mahasiswa masih harus menunggu pemberitahuan jadwal ujian proposal dan komprehensif, serta nilai akhir melalui e-mail. Hal ini tentu menjadi penghambat bagi mahasiswa mengingat waktu yang digunakan cukup lama dikarenakan tidak pemberitahuan tentang e-mail yang masuk dan mahasiswa juga tidak membuka e-mail, sehingga mahasiswa tidak mengetahui kapan jadwal untuk ujian proposal dan komprehensif.

Untuk itulah dibutuhkan aplikasi berbasis mobile sebagai sistem notifikasi tugas akhir mahasiswa berbasis android. Aplikasi mobile "adalah sebuah aplikasi yang memungkinkan untuk melakukan mobilitas dengan menggunakan perlengkapan seperti PDA, telepon seluler atau handphone" [5]. Aplikasi mobile "adalah perangkat lunak yang berjalan pada perangkat mobile seperti smartphone atau tablet PC. Aplikasi mobile juga dikenal sebagai aplikasi yang dapat diunduh dan memiliki fungsi tertentu sehingga menambah fungsionalitas dari perangkat mobile itu sendiri. Untuk mendapatkan aplikasi mobile yang diinginkan, user dapat mengunduhnya melalui situs tertentu sesuai dengan sistem operasi yang dimiliki. Google Play dan iTunes merupakan beberapa contoh dari situs yang menyediakan beragam aplikasi bagi pengguna Android dan iOS untuk mengunduh aplikasi yang diinginkan" [6]. "Untuk menunjang kinerja suatu institusi atau organisasi sebuah teknologi informasi sangatlah dibutuhkan, dengan adanya teknologi informasi tingkat efisiensi dan efektivitas dari sebuah proses akan meningkat, salah satunya adalah dengan munculnya aplikasi mobile yang dapat memudahkan pengguna melakukan suatu transaksi maupun memperoleh informasi" [7].

Aplikasi ini menggunakan teknologi firebase dari google. Firebase "adalah Backend as a Service (BaaS) yang saat ini dimiliki oleh Google. Firebase merupakaan solusi yang ditawarkan oleh Google untuk mempermudah pengembangan aplikasi mobile. Salah satu fitur firebase adalah adanya fitur pendukung untuk aplikasi yang memerlukan push notification yaitu Firebase Notification Console" [8]. Firebase "adalah API yang disediakan google untuk penyimpanan dan penyelarasan data ke dalam aplikasi Android, iOS, atau web. Firebase memiliki banyak fitur seperti authentication, database, storage, hosting, pemberitahuan dan lain-lain" [9]. "Google Firebase menyediakan realtime database NoSQL dengan struktur data JSON (JavaScript Notation) yang dapat dengan mudah diakses melalui kode web di aplikasi hybrid. Selain realtime database, Google Firebase juga menyediakan fitur autentikasi pengguna (menggunakan email dan password), storage (sebagai ruang penyimpanan file) dan cloud messaging (dapat digunakan untuk mengirim notifikasi)" [10]. 
Tujuan penelitian ini untuk menghasilkan aplikasi sistem notifikasi tugas akhir di Universitas Bina Darma berbasis mobile android, guna membantu penyampaian notifikasi seperti jadwal ujian dan nilai ujian untuk tugas akhir kepada mahasiswa yang mengikuti matakuliah proposal dan tugas akhir sehingga dapat mempermudah penyampaian informasi atau pemberitahuan seperti jadwal ujian serta nilai dari hasil ujian untuk tugas akhir mahasiswa di Universitas Bina Darma dan mampu mengatasi permasalahan dalam penyampaian notifikasi (pemberitahuan) tugas akhir bagi mahasiswa di Universitas Bina Darma.

\section{TINJAUAN PUSTAKA}

Beberapa penelitian yang telah dilakukan tentang sistem notifikasi antara lain, penelitian yang dilakukan oleh Siddik dan Nasution dengan judul "Teknologi Push Notifikasi Berbasis Android untuk Informasi Perkuliahan Studi Kasus di STMIK Royal Kisaran", menyatakan bahwa "penelitian tersebut bertujuan untuk memudahkan mahasiswa dalam mendapatkan informasi perkuliahan dan informasi kegiatan yang ada, yang terintegrasi dengan smartphone Android. Aplikasi ini dibuat dengan memanfaatkan teknologi firebase untuk mengirim informasi dalam bentuk push notification" [11]. Penelitian tersebut membuat aplikasi untuk informasi perkuliahan dengan memanfaatkan teknologi push notification dengan mengirimkan informasi kepada mahasiswa tentang kegiatan akademik kampus.

Penelitian lainnya yang dilakukan oleh Ramadhan dan Utomo dengan judul "Rancang Bangun Aplikasi mobile untuk Notifikasi Jadwal Kuliah Berbasis Android Studi Kasus di STMIK ProVisi Semarang", menyatakan bahwa "aplikasi mobile dapat menjadi media pilihan baru bagi mahasiswa untuk mengakses jadwal perkuliahan di STMIK ProVisi. Kemampuan aplikasi mobile menghadirkan data secara otomatis dapat mempermudah mahasiswa untuk mendapatkan jadwal perkuliahan terbaru di STMIK ProVisi Semarang" [12]. Penelitian tersebut menghasilkan sebuah aplikasi mobile berbasis android tentang jadwal perkuliahan dengan mengirimkan notifikasi kepada mahasiswa tentang jadwal perkuliahan yang harus dijalankan.

Berdasarkan beberapa penelitian yang telah dapat disimpulkan bahwa penelitian tersebut samasama membangun sistem notifikasi berbasis mobile android dengan memanfaatkan teknologi push notification tentang informasi kegiatan akademik kampus. Perbedaan penelitian tersebut dengan penelitian yang dilakukan adalah sistem yang akan dibangun adalah sistem notifikasi tentang tugas akhir mahasiswa sedangkan penelitian yang sudah dilakukan merupakan penelitian tentang sistem informasi perkuliahan.

\section{METODE PENELITIAN}

Metode penelitian yang digunakan adalah metode deskriptif kualitatif. Metode deskriptif kualitatif "adalah metode pengolahan data dengan cara menganalisa faktor-faktor yang berkaitan dengan objek penelitian dengan penyajian data secara lebih mendalam terhadap objek penelitian" [13].

Metode pengumpulan data yang digunakan adalah observasi, studi dokumen dan wawancara. Observasi dilakukan dengan cara mengamati langsung objek penelitian yaitu mengamati proses mulai dari pengajuan judul sampai dengan menunggu jadwal ujian. Studi dokumentasi dilakukan dengan mencari dokumen pendukung dalam bentuk buku maupun jurnal. Wawancara dilakukan dengan mahasiswa dan kaprodi mengenai proses administrasi pengajuan tugas akhir sampai dengan jadwal ujian.

Metode pengembangan sistem yang digunakan dalam penelitian ini adalah metode Mobile-D. "Mobile-D merupakan metodologi pembangunan perangkat lunak khusus dirancang untuk pengembangan aplikasi mobile yang didasarkan pada praktek agile. Karakteristik pada metode mobileD yaitu skala kecil, perangkat lunak aplikasi yang dikembangkan dalam lingkungan yang sangat dinamis oleh tim kecil menengah, dengan menggunakan pendekatan berorientasi objek, dalam siklus pengembangan yang relatif singkat"[14]. 


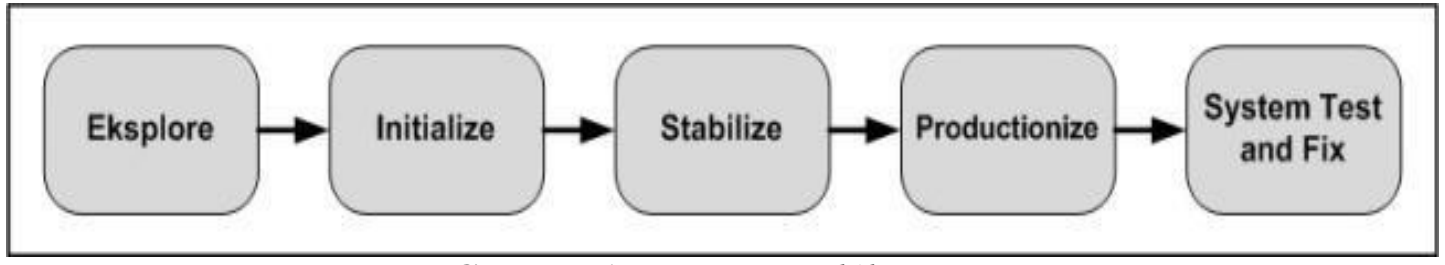

Gambar 1 Tahapan mobile-D[15]

Penjelasan tahapan metode pengembangan mobile- $D$ seperti pada Gambar 1 adalah:

1) Explore, pada tahap ini meliputi pembangunan arsitektur aplikasi berupa pemodelan sistem dalam bentuk use case, class diagram dan activity diagram.

2) Initialize, pada tahap ini selanjutnya akan menterjemahkan rancangan arsitektur sistem menjadi rancangan antarmuka aplikasi sistem notifikasi.

3) Productionize, tahapan ini merupakan tahapan menterjemahkan rancangan ke dalam bentuk aplikasi yang sebenarnya.

4) Stabilize, pada tahapan ini dipastikan bahwa sub-sub aplikasi yang sudah jadi akan disatukan menjadi suatu satu kesatuan aplikasi sistem secara utuh menjadi sistem notifikasi.

5) System test and fix, tahapan ini dilakukan pengujian terhadap aplikasi mobile dan sistem pengiriman notifikasi yang sudah dibuat. Pengujian dilakukan dengan metode black box testing.

\section{HASIL DAN PEMBAHASAN}

Hasil penelitian ini berupa aplikasi sistem notifikasi Tugas Akhir bagi mahasiswa UBD berbasis mobile android yang hanya sebatas format apk saja dan belum tersedia di google playstore. Untuk menjalankan aplikasi mobile android notifikasi tugas akhir UBD, tentunya memerlukan koneksi internet supaya perangkat lunak dapat terhubung ke sistem dan dapat menerima notifikasi. Supaya mahasiswa dapat menggunakan perangkat lunak ini, mahasiswa harus melakukan login terlebih dulu untuk dapat menggunakan fungsi-fungsi yang ada di dalam aplikasi.

\subsection{Explore}

Tahap ini peneliti melakukan perencanaan dan penyusunan terhadap aplikasi yang akan dibuat, tahap tersebut meliputi perangkat lunak untuk membangun aplikasi dan arsitektur aplikasi berupa pemodelan sistem dalam bentuk use case, class diagram dan activity diagram.

Perangkat lunak yang digunakan untuk membangun sistem yaitu Tools Android Studio untuk pembuatan perangkat lunak Mobile dan Notepad++, Sublime Text Editor beserta Xampp yang digunakan dalam pembuatan sistem dummy untuk pengiriman notifikasi.

Rancangan use case diagram sistem seperti pada Gambar 2 dapat dilihat bahwa, aktor/user dalam sistem ini terdiri dari mahasiswa dan petugas PPM (Pusat Pelayanan Mahasiswa). Untuk dapat mengakses sistem mahasiswa dan petugas PPM harus melakukan login terlebih dahulu agar dapat menggunakan menu atau fungsi yang tersedia pada sistem. Menu yang dapat diakses oleh mahasiswa antara lain menu beranda, melihat jadwal ujian, melihat nilai ujian, melihat notifikasi, sedangkan menu yang dapat diakses oleh petugas PPM antara lain menu beranda, menu daftar mahasiswa, menu pengiriman notifikasi dan menu untuk memproses jadwal dan nilai mahasiswa.

Activity diagram menunjukkan interaksi yang dilakukan oleh aktor terhadap sistem. Activity diagram sistem ini terdiri dari activity digram untuk mahasiswa dan activity diagram untuk admin dalam hal ini adalah PPM. Activity diagram mahasiswa dapat dilihat pada Gambar 3. 


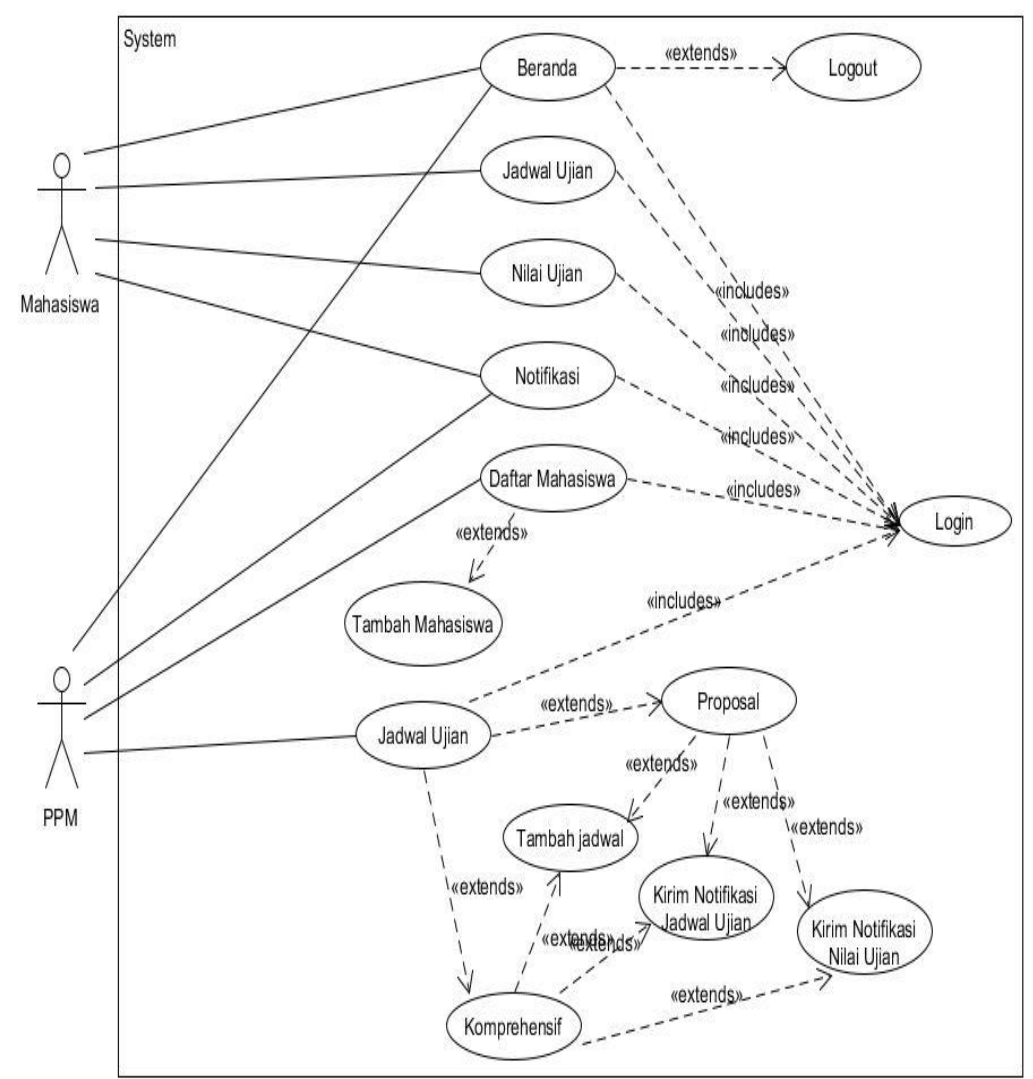

Gambar 2 Use case diagram sistem

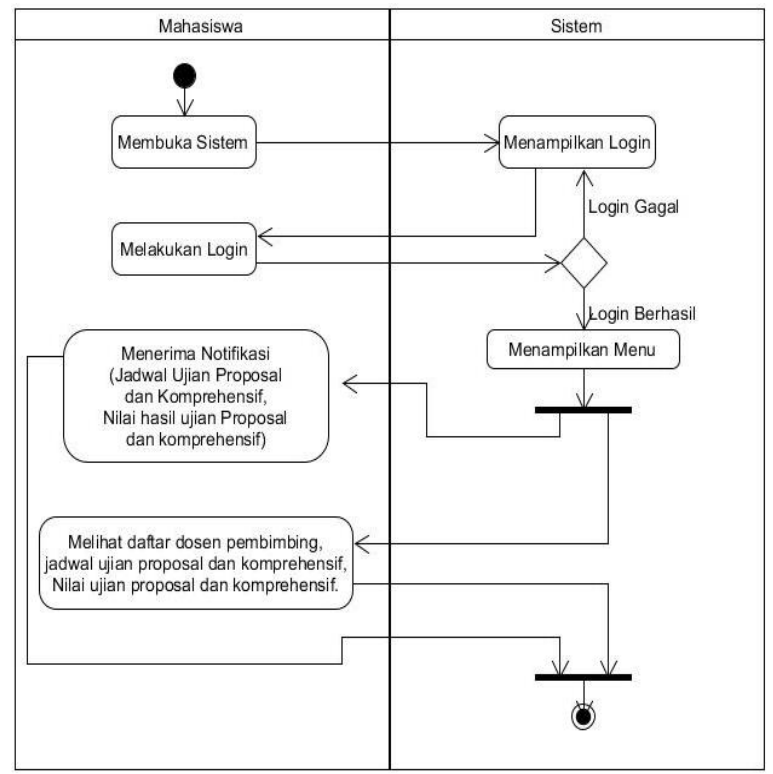

Gambar 3 Activity diagram mahasiswa

Dari Gambar 3 dapat dilihat bahwa aktor pengguna aplikasi sistem adalah mahasiswa dan harus melakukan login terlebih dahulu pada sistem supaya dapat melihat menu seperti melihat nama dosen pembimbing, melihat jadwal ujian proposal atau jadwal ujian komprehensif, melihat nilai hasil ujian. Selain itu mahaswa dapat melihat notifikasi yang dikirimkan oleh sistem seperti notifikasi jadwal ujian proposal atau ujian komprehensif serta dapat melihat pemberitahuan nilai hasil ujian. Selanjutnya Activity diagram PPM dapat dilihat pada Gambar 4. 


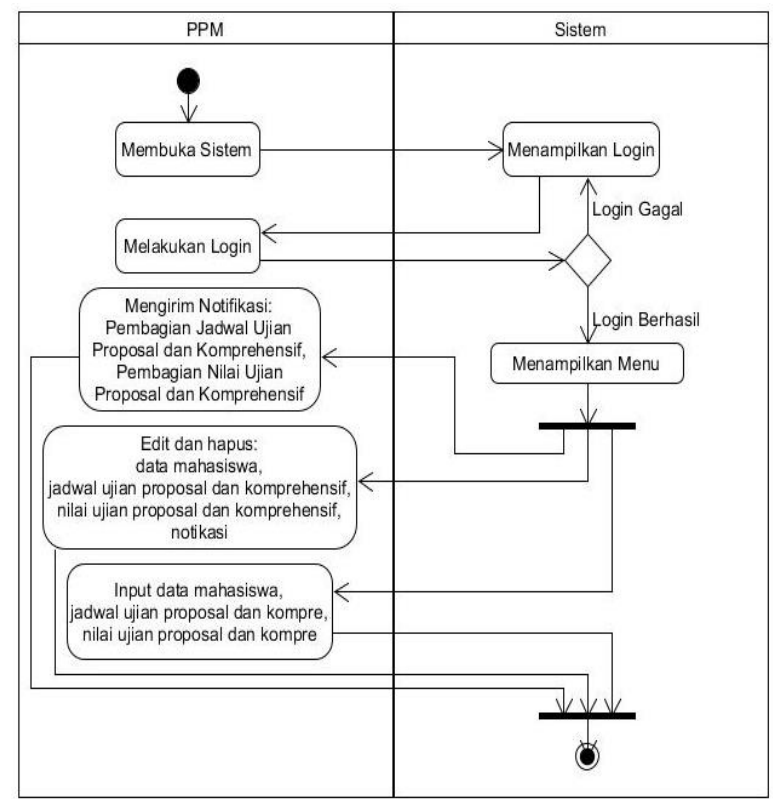

\section{Gambar 4 Activity diagram PPM}

Gambar 4 menujukkan bahwa aktor pengguna sistem pengiriman notifikasi yang bertugas menginput data mahasiswa dan melakukan pengiriman notifikasi adalah PPM (Pusat Pelayanan Mahasiswa). Petugas PPM harus melakukan login terlebih dahulu pada sistem agar dapat melakukan pengolahan data mahasiswa yang mendaftar untuk ujian proposal atau ujian komprehensif, serta menginput jadwal ujian proposal dan komprehensif, menginputkan nilai ujian mahasiswa serta petugas dapan melakukan pengiriman notifikasi kepada mahasiswa.

Class Diagram menggambarkan tentang informasi yang ditampilkan sistem. Class Diagram sistem ini terdiri dari 8 class yang terdiri dari class login, class notifikasi, class menu sistem, class beranda, class FCM, class jadwal ujian, class nilai ujian dan class logout. Setiap kelas terdiri dari beberapa atribut dan berbagai jenis operasinya yang dapat dilihat dengan jelas pada Gambar 5.

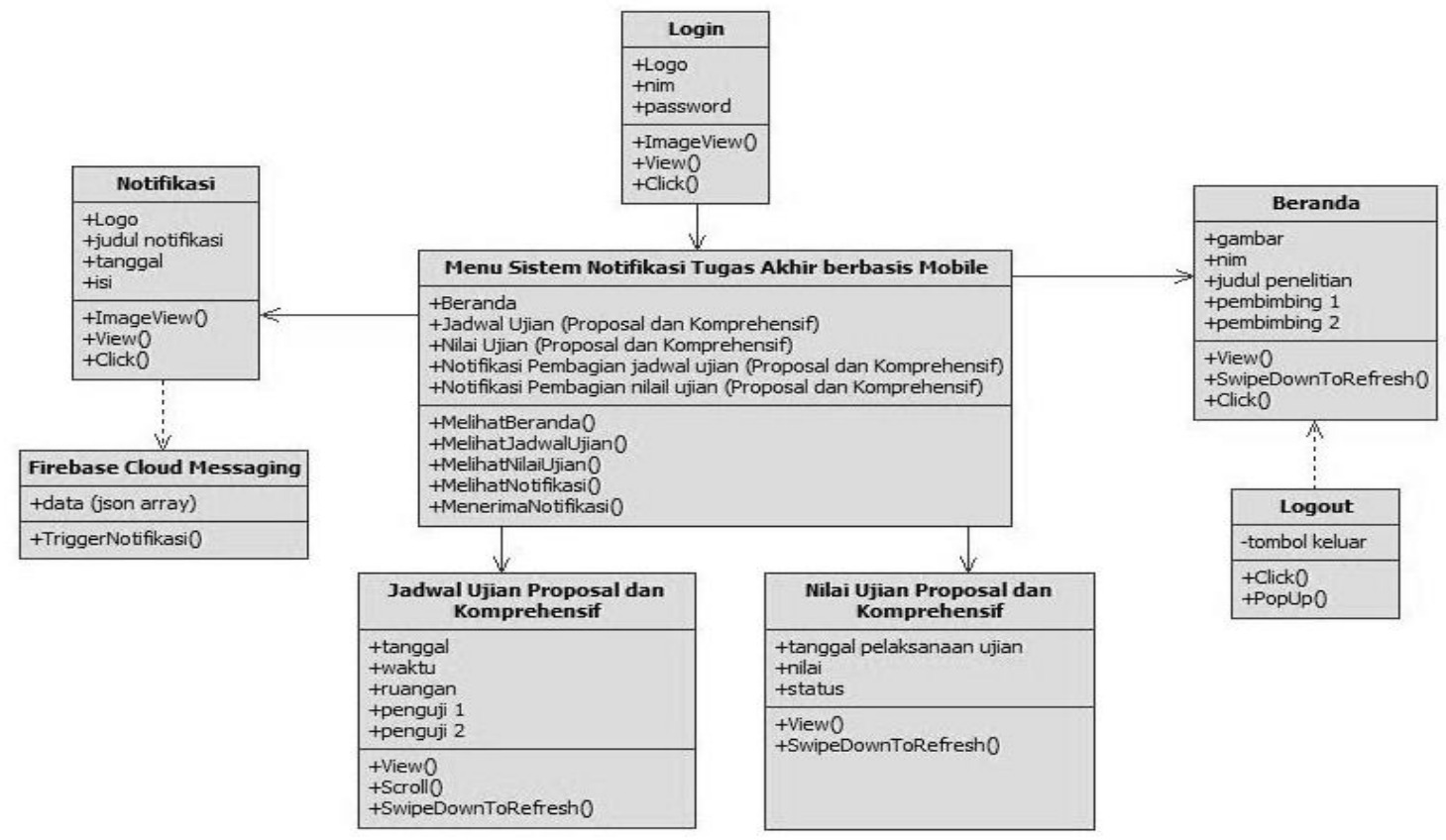

Gambar 5 Class diagram sistem 


\subsection{Initialize}

Pada tahap ini, akan diterjemahkan rancangan arsitektur sistem menjadi rancangan antarmuka aplikasi sistem notifikasi tugas akhir UBD. Gambar 6 dan Gambar 7 merupakan salah satu rancangan antar muka aplikasi.

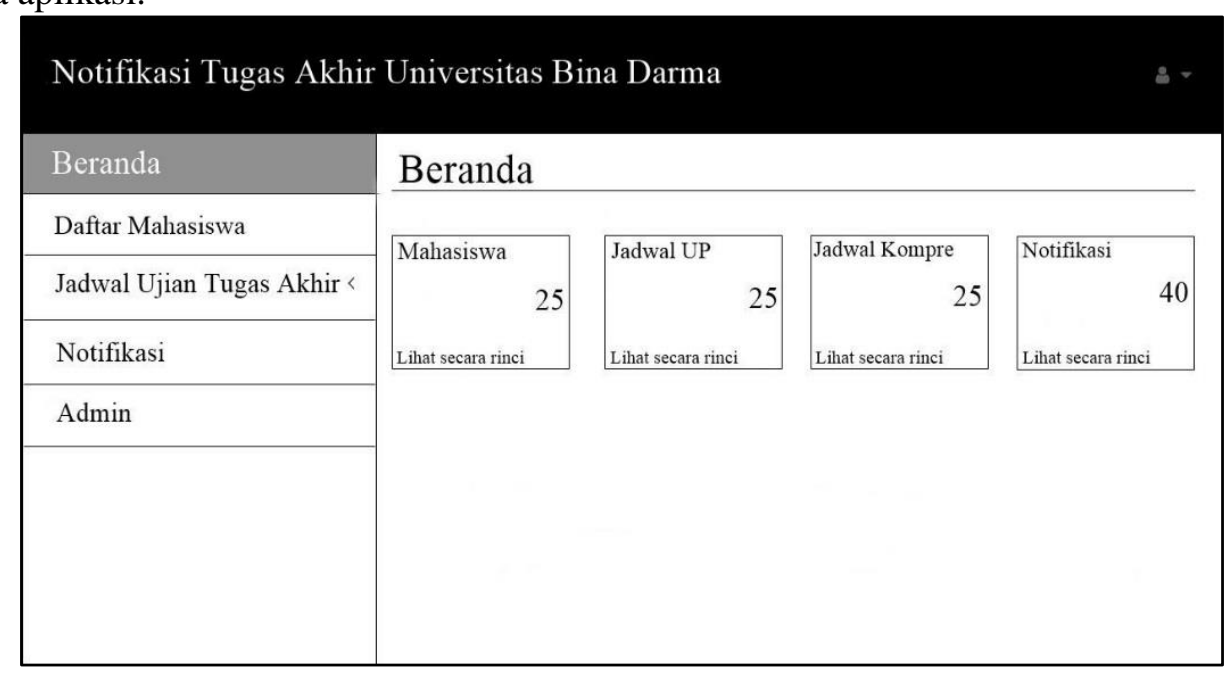

Gambar 6 Desain menu sistem pengiriman notifikasi

Gambar 6 merupakan rancangan menu untuk sistem pengiriman notifikasi seperti Beranda yang berisi tampilan singkat perhitungan jumlah data mahasiswa yang mendaftar, jumlah data ujian proposal dan komprehensif, sedangkan pada bagian Daftar Mahasiswa akan berisi tampilan yang berisi data seperti nim dan nama mahasiswa beserta nama dosen pembimbing serta judul penelitian mahasiswa, pada bagian jadwal ujian akan terbagi menjadi 2 yaitu jadwal ujian proposal dan ujian komprehensif, pada bagian notifikasi terdapat tampilan yang berisi list notifikasi yang sudah terkirim ke perangkat lunak mobile android dan sudah tersimpan pada database sistem.

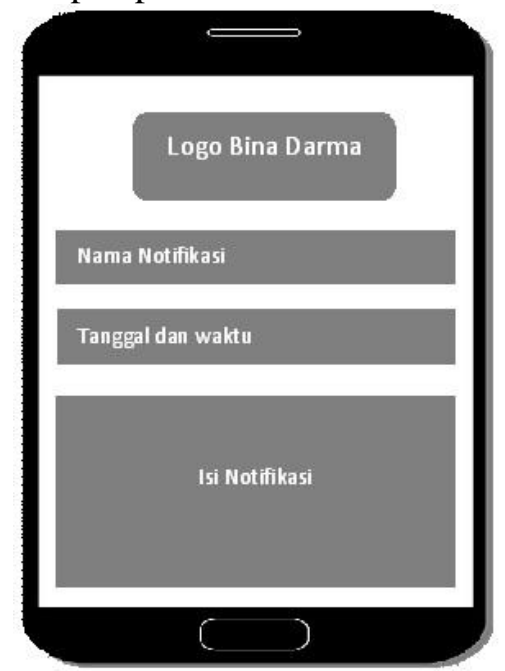

\section{Gambar 7 Desain menu notifikasi}

Gambar 7 merupakan desain menu notifikasi pada android. Menu notifikasi akan menampilkan list notifikasi yang sudah dikirim oleh sistem dan sudah disimpan dalam database sistem. Pada menu ini mahasiswa dapat mengklik atau memilih list tersebut untuk melihat isi notifikasi secara lengkap (detail).

\subsection{Productionize}

Tahap Productionize merupakan tahapan menterjemahkan rancangan ke dalam bentuk aplikasi yang sebenarnya. Aplikasi sistem notifikasi tugas akhir UBD berbasis mobile terdiri dari dua buah sistem yaitu sistem berbasis android yang digunakan oleh mahasiswa dalam bentuk file apk dan sistem 
berbasis web yang digunakan oleh admin untuk mengolah data dan mengirimkan notifikasi ke aplikasi android. Salah satu menu notifikasi untuk user yang berbasis android dapat dilihat pada Gambar 8 dan Gambar 9.

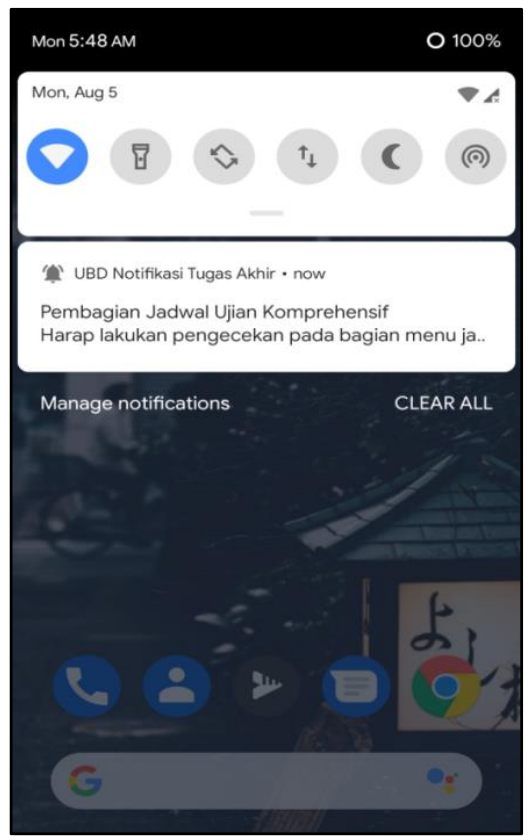

\section{Gambar 8 Menu notifikasi user}

Gambar 8 merupakan tampilan menu notifikasi yang diterima oleh user. Sistem akan menampilkan notifikasi yang dikirimkan oleh sistem notifikasi tugas akhir UBD, notifikasi tersebut di kirim dengan bantuan firebase dari sistem pengiriman notifikasi ke sistem notifikasi tugas akhir UBD. Notifikasi yang akan diterima yaitu notifikasi pembagian jadwal ujian proposal dan ujian komprehensif dan notifikasi nilai dari hasil ujian proposal dan ujian komprehensif.

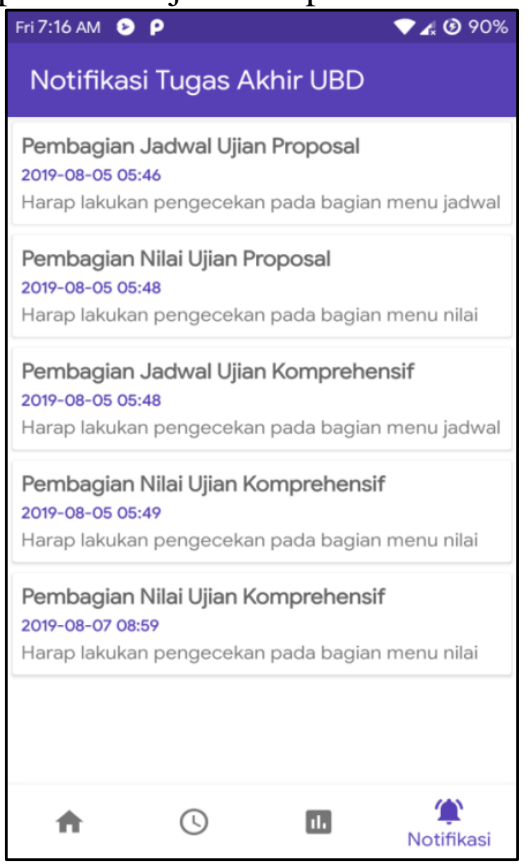

\section{Gambar 9 Menu detail notifikasi user}

Gambar 9 merupakan notifikasi untuk pengguna. Menu ini akan menampilkan notifikasi yang sudah berhasil di terima oleh mahasiswa dan sudah tersimpan dalam database sistem. Notifikasi ini bisa dipilih untuk melihat notifikasi secara lengkat (detail).

Pada sistem pengiriman notifikasi, peneliti menggunakan sistem yang berbasis website PHP untuk mengolah data mahasiswa yang sudah mendaftar untuk ujian proposal atau ujian komprehensif oleh

Ryan Andri, Nurul A.O Saputri, Muhamad Akbar, Sistem Notifikasi Tugas Akhir Universitas Bina Darma Berbasis Mobile 
PPM sebagai pengguna sistem pengiriman notifikasi ini. Dalam penelitian ini, peneliti menggunakan data dummy dikarenakan sistem ini untuk menguji tujuan dari peneliti. Tampilan halaman sistem untuk pengolahan data berbasis web dapat dilihat pada Gambar 10 dan Gambar 11.

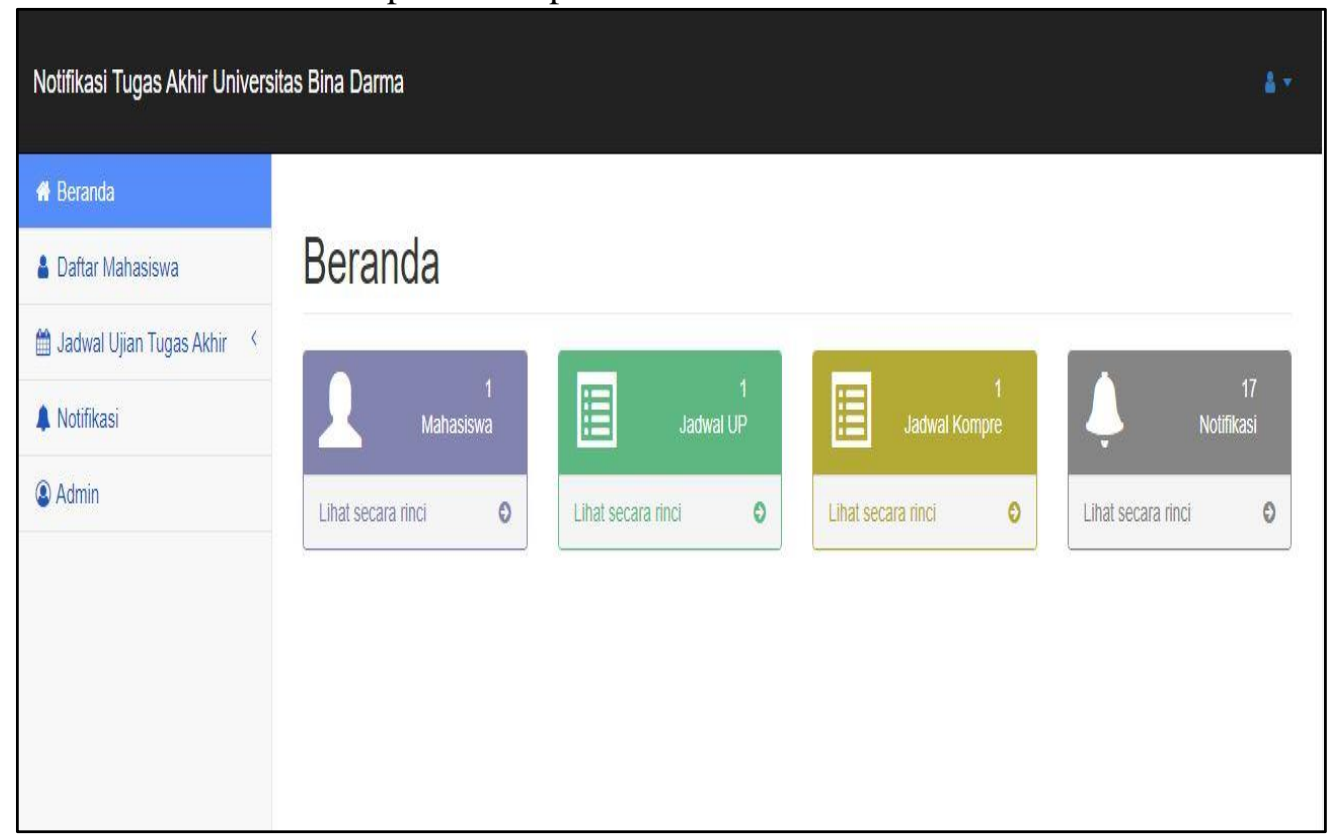

Gambar 10 Halaman beranda sistem

Gambar 10 merupakan halaman beranda berbasis web yang digunakan oleh PPM untuk mengolah data dan mengirimkan notifikasi kepada aplikasi berbasis android mahasiswa. Halaman ini terdiri dari beberapa menu seperti menu mahasiswa, menu jadwal ujian proposal, menu jadwal komprehensif dan menu notifikasi untuk pengiriman notifikasi.

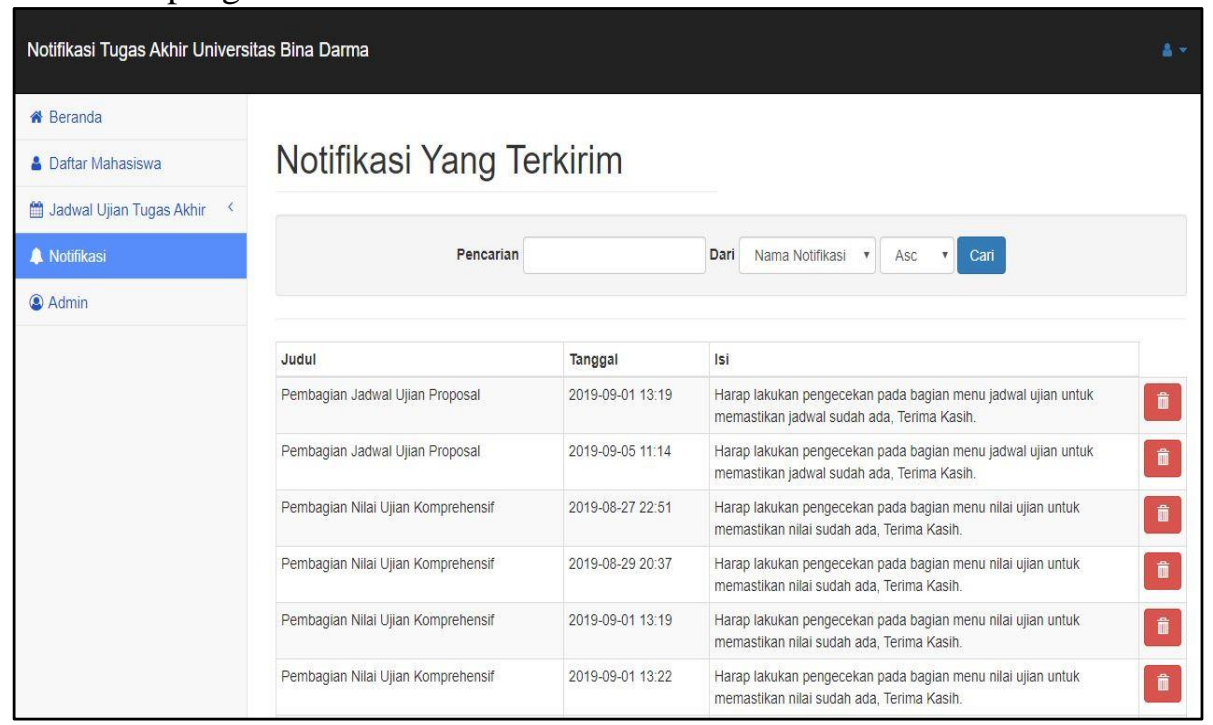

Gambar 11 Halaman notifikasi terkirim

Gambar 11 menunjukkan seluruh notifikasi yang telah berhasil terkirim dan disimpan ke dalam database.

\subsection{Stabilize}

Tahapan stabilize merupakan tahapan menyatukan sub-sub sistem menjadi suatu satu kesatuan aplikasi sistem secara utuh. Tahapan ini untuk memastikan bahwa aplikasi yang sudah jadi, diintegrasikan dengan sistem pengiriman notifikasi agar aplikasi mobile dapat menggunakan database 
yang sama sehingga pengguna (mahasiswa) dapat login dengan perangkat lunak mobile yang sudah dibuat.

Pada tahap ini, peneliti membuat sebuah file php yang dinamakan "Api.php" pada sistem pengiriman notifikasi. File tersebut mengimplementasikan JSON sebagai koneksi perangkat lunak mobile untuk mendapatkan data dari sistem pengiriman notifikasi yang berupa data mahasiswa, jadwal beserta nilai ujian proposal dan komprehensif.

\subsection{System Test and Fix}

Tahapan terakhir adalah tahapan System Test and Fix. Pada tahap ini peneliti melakukan pengujian (Testing) terhadap aplikasi mobile dan sistem pengiriman notifikasi yang sudah dibuat, serta melakukan perbaikan (Fix) apabila terdapat kode program atau bagian dari perangkat lunak yang tidak berjalan sesuai tujuan. Pengujian dilakukan dengan metode Black Box Testing terhadap aplikasi berbasis android dan sistem pengiriman notifikasi yang berbasis web. Hasil pengujian aplikasi android dapat dilihat pada Tabel 1.

Tabel 1 Hasil Pengujian Aplikasi Berbasis Android

\begin{tabular}{cllc}
\hline No & Skenario Pengujian & \multicolumn{1}{c}{ Hasil yang Diharapkan } & Kesimpulan \\
\hline 1 & Login dengan nim dan & Menampilkan dialog "Semua & Valid \\
& password yang kosong. & Kolom harus diisi" \\
2 & $\begin{array}{l}\text { Login dengan Nim dan } \\
\text { Menampikan dialog "Nim atau }\end{array}$ & Valid \\
& $\begin{array}{l}\text { Password yang salah. } \\
\text { Memilih (klik) tombol }\end{array}$ & $\begin{array}{l}\text { Password salah" } \\
\text { Menampilkan dialog pilihan } \\
\text { logout }\end{array}$ & Valid \\
& keluar jika dipilih" "iya". & \\
\hline
\end{tabular}

Selanjutnya hasil pengujian black box terhadap sistem pengiriman notifikasi yang berbasis web dapat dilihat pada Tabel 2.

Tabel 2 Hasil Pengujian Sistem Pengiriman Notifikasi

\begin{tabular}{|c|c|c|c|}
\hline No & Skenario Pengujian & Hasil yang Diharapkan & Kesimpulan \\
\hline 1 & $\begin{array}{l}\text { Login dengan } \\
\text { username dan } \\
\text { password yang salah }\end{array}$ & $\begin{array}{l}\text { Menampilkan info "Invalid } \\
\text { username atau password" }\end{array}$ & Valid \\
\hline 2 & $\begin{array}{l}\text { Input data mahasiswa } \\
\text { untuk mendaftar ujian }\end{array}$ & $\begin{array}{l}\text { Berhasil input data mahasiswa } \\
\text { dan menampilkan pada tabel } \\
\text { yang terdapat pada menu } \\
\text { "Mahasiswa" }\end{array}$ & Valid \\
\hline 3 & $\begin{array}{l}\text { Input jadwal ujian } \\
\text { proposal mahasiswa }\end{array}$ & $\begin{array}{l}\text { Berhasil input data jadwal ujian } \\
\text { proposal untuk mahasiswa yang } \\
\text { sudah mendaftar }\end{array}$ & Valid \\
\hline 4 & $\begin{array}{l}\text { Input jadwal } \\
\text { Komprehensif } \\
\text { mahasiswa }\end{array}$ & $\begin{array}{l}\text { Berhasil input data jadwal ujian } \\
\text { kompre untuk mahasiswa yang } \\
\text { sudah mendaftar. }\end{array}$ & Valid \\
\hline 5 & $\begin{array}{l}\text { Uji tombol Kirim } \\
\text { notifikasi }\end{array}$ & $\begin{array}{l}\text { Menampilkan info "Notifikasi } \\
\text { berhasil dikirim dan disimpan" }\end{array}$ & Valid \\
\hline
\end{tabular}

\section{KESIMPULAN}

Berdasarkan hasil penelitian dapat disimpulkan bahwa penelitian ini menghasilkan sebuah produk berupa aplikasi sistem notifikasi tugas akhir Universitas Bina Darma berbasis mobile dengan mengikuti alur pengembangan perangkat lunak Mobile- $D$ yang dapat membantu mempermudah penyampaian 
informasi kepada mahasiswa dalam bentuk notifikasi melalui smartphone android seperti jadwal ujian dan nilai ujian untuk tugas akhir.

\section{REFERENSI}

[1] A. Nasution, "Perancangan Aplikasi Push Notification Berbasis Android," JURTEKSI, vol. 4, no. 2, pp. 149-154, 2018.

[2] M. Z. Faried, A. Mulwinda, and Y. Primadiyono, "Pengembangan Aplikasi Android Bimbingan Skripsi dengan Fitur Notifikasi," J. Tek. Elektro, vol. 9, no. 2, pp. 74-79, 2017.

[3] L. Rusdiana and H. Setiawan, "Perancangan Aplikasi Monitoring Kesehatan Ibu Hamil Berbasis Mobile Android," SISTEMASI, vol. 7, no. 3, pp. 197-203, 2018.

[4] W. A. Kusuma, "Sistem Informasi Geografis Pemetaan Lokasi Bird Contest Kota Malang Berbasis Android," SISTEMASI, vol. 7, no. 3, pp. 212-219, 2018.

[5] S. Surahman and E. B. Setiawan, "Aplikasi Mobile Driver Online Berbasis Android Untuk Perusahaan Rental Kendaraan," Ultim. InfoSys J. Ilmu Sist. Inf., vol. 8, no. 1, pp. 35-42, 2017.

[6] M. Irsan, "Rancang bangun aplikasi mobile notifikasi berbasis android untuk mendukung kinerja di instansi pemerintahan,” J. Sist. dan Teknol. Inf., vol. 3, no. 1, pp. 115-120, 2015.

[7] K. R. Hadi, H. M. Az-zahra, and L. Fanani, "Analisis Dan Perbaikan Usability Aplikasi Mobile KAI Access Dengan Metode Usability Testing Dan Use Questionnaire," J. Pengemb. Teknol. Inf. Dan Ilmu Komput., vol. 2, no. 9, pp. 2742-2750, 2018.

[8] L. A. Sandy, R. J. Akbar, and R. R. Hariadi, "Rancang Bangun Aplikasi Chat pada Platform Android dengan Media Input Berupa Canvas dan Shareable Canvas untuk Bekerja dalam Satu Canvas Secara Online," J. Tek. ITS, vol. 6, no. 2, pp. 331-336, 2017.

[9] G. R. Payara and R. Tanone, "Penerapan Firebase Realtime Database Pada PrototypeAplikasi Pemesanan Makanan Berbasis Android," J. Tek. Inform. dan Sist. Inf. p-ISSN, vol. 2443, p. 2210.

[10] M. Ilhami, "Pengenalan Google Firebase Untuk Hybrid Mobile Apps Berbasis Cordova," IT CIDA, vol. 3, no. 1, 2018.

[11] M. Siddik and A. Nasution, "Teknologi Push Notifikasi Berbasis Android Untuk Informasi Perkuliahan (Studi Kasus: STMIK Royal Kisaran)," in Seminar Nasional Royal (SENAR), 2018, vol. 1, no. 1, pp. 41-44.

[12] T. Ramadhan and V. G. Utomo, "Rancang Bangun Aplikasi Mobile untuk notifikasi Jadwal Kuliah Berbasis Android (Studi Kasus STMIK Provisi Semarang)," J. Teknol. Inf. dan Komun., vol. 5, no. 2, pp. 868-2087, 2014.

[13] A. Prabowo and H. Heriyanto, "Analisis pemanfaatan buku elektronik (e-book) oleh pemustaka di perpustakaan SMA Negeri 1 Semarang," J. Ilmu Perpust., vol. 2, no. 2, pp. 152-161, 2013.

[14] R. Rizki, A. Y. Ranius, and A. Muzakir, "Implementasi Metode Mobile-D Untuk Pembuatan Ensiklopedia Kebudayaan Kota Palembang Berbasis Android," J. Mhs. Tek. Inform., 2014.

[15] N. A. O. Saputri and R. M. N. Halim, "Aplikasi Peta Titik Rawan Banjir di Kota Palembang," J. Teknol. Inf. dan Ilmu Komput., vol. 6, no. 4, pp. 450-455, 2019. 